\title{
TUBADIL IN OPHTHALMIC SURGERY* ITS EFFECT ON INTRA-OCULAR PRESSURE
}

\author{
BY \\ R. BRYCE-SMITH AND F. K. BOSTON \\ United Oxford Hospitals
}

ON several occasions d-tubocurarine has been used intravenously in conjunction with local analgesia for ophthalmic surgery (Kirby, 1950; Farquharson, 1951). The object has been to administer just sufficient to provide a quiet, immobile field for the surgeon, without causing respiratory embarrassment or unpleasant subjective symptoms in the patient. Probably these requirements are never fulfilled entirely, the result being a compromise. It is debatable whether the conditions provided have any advantage over the standard local analgesic technique which incorporates a facial nerve block. Both methods have the disadvantage of a limited duration of effect, which, although adequate for any surgical procedure, will be insufficient to influence the post-operative period.

A technique which would provide ideal operating conditions and would also protect the patient from spasm of the orbicularis oculi during the ensuing 24-hour period, when the risks of such complications as iris prolapse are highest, would have obvious virtues. With this in mind, a preparation which liberated d-tubocurarine slowly from a wax base was investigated. The preparation chosen was Tubadil $\dagger$, since the reports of its duration of effect in other fields of medicine were encouraging (Hoback, 1952; Fuller, 1950; Norcross, Robins, and Lockie, 1949).

Tubadil.-This preparation is a mixture of bees' wax, peanut oil, and oxycholesterols, containing $25 \mathrm{mg}$. d-tubocurarine per $\mathrm{ml}$. When cold it is solid, but on gentle warming it becomes fluid. If given by deep intramuscular injection it is liberated slowly from this depot. There is experimental evidence which suggests that the toxicity of Tubadil (in terms of respiratory paralysis) is less than that of equivalent doses of intravenous d-tubocurarine in the ratios of 10:1 (intramuscular Tubadil) and 3.5:1 (intravenous Tubadil) (Gordon). These figures emphasize the slow liberation of the active alkaloid from the menstruum, and also demonstrate the safety factor of the mixture.

Injection Technique.-The ampoule of Tubadil is placed in water at about $60^{\circ} \mathrm{C}$. (as hot as the hand can tolerate). When the contents have become fluid, the ampoule is shaken vigorously to ensure uniform mixing, and the chosen dose is then drawn up into a dry, sterile, syringe through a No. 1 hypodermic needle. $\ddagger$

* Received for publication July 3, 1958

Registered trade name of Endo Products Inc. for a repository form of d-tubocurarine.

$\$$ A No. 1 hypodermic needle has an outer diameter of $0.81 \mathrm{~mm}$. and a length of $38 \mathrm{~mm}$., and is equivalent to a 21 S.W.G. 
To avoid too rapid cooling of the mixture, which might make injection difficult, the syringe and needle should also be warmed.

The injection must be made into a muscle mass, preferably the gluteal, as a single insertion. Heat must not be applied nor the area massaged, since these measures may increase the rate of liberation of d-tubocurarine to a dangerous extent.

Previous Uses of Tubadil.-This drug has been used during the past 10 years for a variety of conditions in which muscle spasm has been present. Originally, indications were found in neurological diseases which included tetanus (Weed, Purvis, and Warnke, 1948; Honey, Dwyer, Smith, and Spalding, 1954). More recently it has proved of value in the relief of sphincter spasm and hence pain following anal operations (Malia, Lucas, Burns, and Whitacre, 1954). The doses have been adjusted to meet requirements, but with growing confidence in the safety of the preparation they have been increased to give better relaxation without causing undesirable side-effects.

\section{Present Investigation}

It was hoped that Tubadil would abolish the need for a facial nerve block by providing a relaxed orbicularis oculi at the time of operation, and preventing the tendency to "squeeze" during the early post-operative period. Tubadil was administered 2 hours pre-operatively to a group of patients about to undergo surgery for cataract extraction. Before receiving the drug, each individual was tested for vital capacity, hand grip with a dynamometer, and ocular tension.* 90 minutes later, before the injection of local analgesia and the beginning of surgery, these tests were repeated.

24 patients were chosen for the investigation, whose ages ranged from 42 to 85 years. Without selection they were divided into four groups of six subjects each. The first group received $0 \cdot 75-1 \cdot 25 \mathrm{ml}$. Tubadil, the second group 1.65-2.0 ml., the third group 2.5-3 ml., and the fourth group two injections of $1 \mathrm{ml}$. The injections were given 2 hours before operation, at the same time as premedication with intramuscular phenobarbitone.

\section{Results}

In none of these patients, even those who received as much as $75 \mathrm{mg}$. d-tubocurarine, was it possible to provide sufficiently relaxed eyelids to dispense with the necessity for a facial nerve block. Ptosis was seen on occasion, also a lateral nystagmus, suggesting partial paralysis of the external ocular muscles. Hand dynamometer readings showed little change, and although there was frequently a slight fall in vital capacity, this was insufficient to be considered of clinical significance. No subjective symptoms attributable to the Tubadil were observed either in these patients or in six others who received Tubadil in comparable doses for a further series of tests.

The most noticeable result of this investigation was the fall in ocular tension which was encountered in the majority of patients. The greatest

\footnotetext{
* Ocular tension was measured with a Schiötz tonometer (Weiss) and the same instrument was used throughout
} with a loading of $5.5 \mathrm{~g}$. The results shown in the accompanying Tables are given all in $\mathrm{mm}$. $\mathrm{Hg}$. 
falls occurred in those who had the highest ocular tensions initially, the maximal effect occurring approximately 2 hours after injection. In those patients who underwent surgery it was impossible to determine the duration of this fall in tension; in consequence, six patients who were being investigated medically for glaucoma were given Tubadil and the ocular tension was measured at 4-hourly intervals thereafter. It would appear that, in spite of varying the dose of Tubadil, the effect lasted for 15 to 24 hours in each patient, the duration bearing little relation to the amount injected (Table I). But it might be assumed from this evidence that the Tubadil would have exerted a considerable effect during the immediate post-operative period if these patients had been submitted to operation.

TABLE I

EFFECT OF TUBADIL IN SIX PATIENTS NOT UNDERGOING SURGERY

\begin{tabular}{|c|c|c|c|c|c|c|c|c|}
\hline \multirow{2}{*}{$\begin{array}{l}\text { Age } \\
\text { (yrs) }\end{array}$} & \multirow{2}{*}{ Sex } & \multicolumn{2}{|c|}{$\begin{array}{c}\text { Initial Ocular Tension } \\
\text { (mm. Hg) }\end{array}$} & \multirow{2}{*}{$\begin{array}{c}\text { Dose of } \\
\text { Tubadil } \\
\text { (ml.) }\end{array}$} & \multicolumn{2}{|c|}{$\begin{array}{c}\text { Lowest Ocular Tension } \\
(\mathrm{mm} . \mathrm{Hg})\end{array}$} & \multirow{2}{*}{$\begin{array}{c}\text { Fall in } \\
\text { Ocular } \\
\text { Tension } \\
\text { (per cent.) }\end{array}$} & \multirow{2}{*}{$\begin{array}{c}\text { Duration } \\
\text { of Effect } \\
\text { (hrs) }\end{array}$} \\
\hline & & Right & Left & & Right & Left & & \\
\hline $\begin{array}{l}82 \\
52 \\
44 \\
33 \\
66 \\
73\end{array}$ & $\begin{array}{l}\mathbf{F} \\
\mathbf{M} \\
\mathbf{M} \\
\mathbf{F} \\
\mathbf{M} \\
\mathbf{F}\end{array}$ & $\begin{array}{l}45 \\
40 \\
35 \\
60 \\
22 \\
30\end{array}$ & $\begin{array}{l}42 \\
35 \\
50 \\
33 \\
22 \\
30\end{array}$ & $\begin{array}{l}3 \\
3 \\
2 \\
2 \\
1 \\
1\end{array}$ & $\begin{array}{l}25 \\
10 \\
25 \\
30 \\
12 \\
20\end{array}$ & $\begin{array}{l}27 \\
12 \\
25 \\
25 \\
15 \\
21\end{array}$ & $\begin{array}{l}44 \\
25 \\
50 \\
50 \\
45 \\
33\end{array}$ & $\begin{array}{l}20 \\
23 \\
17 \\
23 \\
16 \\
15\end{array}$ \\
\hline
\end{tabular}

Of the 24 patients who received Tubadil before surgery (Table II, opposite), eleven showed a fall in ocular tension. All of these remarked on their freedom from discomfort during the post-operative period. Slight or no changes in the ocular tension were found in six patients in whom the tension was almost within the range of normal at the outset. Once more, postoperative freedom from pain was noticeable. The remaining seven patients showed a rise in tension; in five this might be explained by the fact that the second reading was made by a different person-a factor which did not arise with the previous patients. One patient in this last group complained that the post-operative pain was more severe than after an extraction performed one year previously on the other eye.

In a small control group of six patients about to undergo cataract extraction without Tubadil, a similar series of tests (vital capacity, dynamometer reading, and ocular tension) was performed to assess the effect of any premedication that had been given. In this group, the ocular tension remained unchanged in four, showed a slight rise in one, and a slight fall in one (Table III, opposite).

\section{Conclusions}

It appears that Tubadil per se is capable of reducing the ocular tension for several hours. This implies that the mechanism must be due to factors 
TABLE II

EFFECT OF TUBADIL ON 24 PATIENTS ABOUT TO UNDERGO CATARACT EXTRACTION

\begin{tabular}{|c|c|c|c|c|c|c|c|c|c|c|c|}
\hline \multirow{3}{*}{ Group } & \multirow{3}{*}{$\begin{array}{l}\text { Age } \\
\text { (yrs) }\end{array}$} & \multirow{3}{*}{ Sex } & \multicolumn{4}{|c|}{ Initial Findings } & \multirow{3}{*}{$\begin{array}{l}\text { Dose } \\
\text { of Tubadil } \\
(\mathrm{ml} .)\end{array}$} & \multicolumn{4}{|c|}{$\begin{array}{c}\text { Findings } 90 \text { min. after Tubadil } \\
\text { Administration }\end{array}$} \\
\hline & & & \multicolumn{2}{|c|}{$\begin{array}{l}\text { Ocular } \\
\text { Tension } \\
(\mathrm{mm} . \mathrm{Hg})\end{array}$} & \multirow[t]{2}{*}{$\begin{array}{c}\text { Vital } \\
\text { Capacity }\end{array}$} & \multirow{2}{*}{$\begin{array}{l}\text { Hand } \\
\text { Dynamo- } \\
\text { meter }\end{array}$} & & \multicolumn{2}{|c|}{$\begin{array}{c}\text { Ocular } \\
\text { Tension } \\
(\mathrm{mm} . \mathrm{Hg})\end{array}$} & \multirow[t]{2}{*}{$\begin{array}{c}\text { Vital } \\
\text { Capacity }\end{array}$} & \multirow{2}{*}{$\begin{array}{c}\text { Hand } \\
\text { Dynamo- } \\
\text { meter }\end{array}$} \\
\hline & & & Right & Left & & & & Right & Left & & \\
\hline $\begin{array}{c}(1) \\
0 \cdot 75 \\
\text { to } \\
1.25 \\
\mathrm{ml} .\end{array}$ & $\begin{array}{l}73 \\
79 \\
65 \\
77 \\
73 \\
71\end{array}$ & $\begin{array}{l}M \\
F \\
F \\
F \\
M \\
F\end{array}$ & $\begin{array}{l}18 \\
33 \\
27 \\
15 \\
42 \\
25\end{array}$ & $\begin{array}{l}10 \\
22 \\
33 \\
15 \\
42 \\
23\end{array}$ & $\begin{array}{r}1,100 \\
1,900 \\
1,800 \\
1,400 \\
2,100 \\
800\end{array}$ & $\begin{array}{l}15 \\
35 \\
35 \\
16 \\
20 \\
24\end{array}$ & $\begin{array}{l}1 \\
0 \cdot 75 \\
1 \\
1 \\
1 \cdot 1 \\
1 \cdot 25\end{array}$ & $\begin{array}{l}14 \\
25 \\
22 \\
10 \\
25 \\
22\end{array}$ & $\begin{array}{r}24 \\
15 \\
33 \\
10 \\
25 \\
? 40\end{array}$ & $\begin{array}{r}1,000 \\
1,350 \\
1,700 \\
1,150 \\
1,650 \\
700\end{array}$ & $\begin{array}{l}15 \\
45 \\
33 \\
10 \\
18 \\
20\end{array}$ \\
\hline $\begin{array}{l}(2) \\
1.65 \\
\text { to } \\
2 \mathrm{ml}\end{array}$ & $\begin{array}{l}76 \\
54 \\
59 \\
67 \\
77 \\
67\end{array}$ & $\begin{array}{l}M \\
M \\
M \\
F \\
M \\
M\end{array}$ & $\begin{array}{r}42 \\
18 \\
14 \\
22 \\
9 \\
14\end{array}$ & $\begin{array}{r}53 \\
18 \\
14 \\
22 \\
15 \\
7\end{array}$ & $\begin{array}{l}2,800 \\
2,700 \\
3,300 \\
1,600 \\
2,000 \\
2,450\end{array}$ & $\begin{array}{l}20 \\
47 \\
42 \\
32 \\
20 \\
14\end{array}$ & $\begin{array}{l}1 \cdot 65 \\
1 \cdot 7 \\
1 \cdot 75 \\
1 \cdot 8 \\
2 \\
2\end{array}$ & $\begin{array}{l}25 \\
30 \\
14 \\
17 \\
22 \\
10\end{array}$ & $\begin{array}{l}28 \\
30 \\
14 \\
17 \\
33 \\
10\end{array}$ & $\begin{array}{l}2,600 \\
2,300 \\
3,100 \\
1,550 \\
1,800 \\
2,100\end{array}$ & $\begin{array}{l}18 \\
42 \\
42 \\
28 \\
16 \\
14\end{array}$ \\
\hline $\begin{array}{c}(3) \\
2 \cdot 5 \\
\text { to } \\
3 \mathrm{ml}\end{array}$ & $\begin{array}{l}59 \\
85 \\
84 \\
42 \\
72 \\
82 \\
\end{array}$ & $\begin{array}{l}F \\
F \\
F \\
M \\
F \\
M\end{array}$ & $\begin{array}{l}22 \\
22 \\
18 \\
18 \\
22 \\
10\end{array}$ & $\begin{array}{l}18 \\
22 \\
18 \\
14 \\
22 \\
10\end{array}$ & $\begin{array}{l}1,600 \\
1,200 \\
1,550 \\
2,700 \\
1,400 \\
1,450\end{array}$ & $\begin{array}{l}27 \\
13 \\
15 \\
24 \\
34 \\
25\end{array}$ & $\begin{array}{l}2 \cdot 5 \\
2 \cdot 5 \\
2 \cdot 5 \\
2 \cdot 5 \\
3 \\
3\end{array}$ & $\begin{array}{l}22 \\
27 \\
27 \\
14 \\
18 \\
14\end{array}$ & $\begin{array}{l}27 \\
27 \\
22 \\
14 \\
18 \\
25\end{array}$ & $\begin{array}{l}1,300 \\
1,200 \\
1,600 \\
2,600 \\
1,200 \\
1,600\end{array}$ & $\begin{array}{l}21 \\
13 \\
14 \\
22 \\
27 \\
43\end{array}$ \\
\hline $2 \stackrel{(4)}{\mathrm{ml} .}$ & $\begin{array}{l}67 \\
77 \\
68 \\
66 \\
54 \\
78\end{array}$ & $\begin{array}{l}F \\
M \\
F \\
F \\
M \\
M\end{array}$ & $\begin{array}{r}12 \\
25 \\
22 \\
9 \\
18 \\
10\end{array}$ & $\begin{array}{r}12 \\
32 \\
27 \\
9 \\
18 \\
10\end{array}$ & $\begin{array}{r}1,600 \\
2,400 \\
1,300 \\
1,000 \\
3,650 \\
600\end{array}$ & $\begin{array}{l}11 \\
19 \\
15 \\
12 \\
22 \\
15\end{array}$ & $\begin{array}{l}\text { Two } \\
\text { doses } \\
\text { of } \\
1 \mathrm{ml} . \\
\text { each }\end{array}$ & $\begin{array}{r}12 \\
18 \\
18 \\
6 \\
14 \\
10\end{array}$ & $\begin{array}{r}10 \\
18 \\
18 \\
6 \\
10 \\
10\end{array}$ & $\begin{array}{r}900 \\
2,500 \\
1,500 \\
1,050 \\
3,650 \\
650\end{array}$ & $\begin{array}{l}11 \\
19 \\
15 \\
10 \\
19 \\
14\end{array}$ \\
\hline
\end{tabular}

TABLE III

CONTROL SERIES OF SIX PATIENTS NOT GIVEN TUBADIL*

\begin{tabular}{|c|c|c|c|c|c|c|}
\hline \multirow{3}{*}{$\begin{array}{l}\text { Age } \\
\text { (yrs) }\end{array}$} & \multirow{3}{*}{ Sex } & \multicolumn{4}{|c|}{ Ocular Tension } & \multirow{3}{*}{$\begin{array}{c}\text { Effect on } \\
\text { Ocular Tension }\end{array}$} \\
\hline & & \multicolumn{2}{|c|}{ Before Premedication } & \multicolumn{2}{|c|}{2 hours after Premedication } & \\
\hline & & Right & Left & Right & Left & \\
\hline $\begin{array}{l}79 \\
78 \\
64 \\
78 \\
63 \\
74\end{array}$ & $\begin{array}{l}\mathrm{M} \\
\mathrm{M} \\
\mathrm{M} \\
\mathrm{F} \\
\mathrm{F} \\
\mathrm{M}\end{array}$ & $\begin{array}{r}22 \\
14 \\
18 \\
9 \\
15 \\
9\end{array}$ & $\begin{array}{l}22 \\
25 \\
18 \\
11 \\
22 \\
15\end{array}$ & $\begin{array}{l}22 \\
14 \\
27 \\
13 \\
12 \\
12\end{array}$ & $\begin{array}{r}22 \\
25 \\
22 \\
9 \\
15 \\
15\end{array}$ & $\begin{array}{l}\text { Unchanged } \\
\text { Unchanged } \\
\text { Rise } \\
\text { Unchanged } \\
\text { Fall } \\
\text { Unchanged }\end{array}$ \\
\hline
\end{tabular}

* All patients received premedication with 2 gr. (120 mg.) phenobarbitone intramuscularly.

other than relaxation of the external ocular muscles, since it is recognized that the eye quickly accommodates itself to pressure effects from without. It is doubtful whether Tubadil serves any useful purpose in the routine preparation of the average patient who is to undergo cataract extraction, but in those with a high initial ocular tension, with its well-known attendant 
risks, it should be possible to afford some protection for a limited period. We would therefore suggest that in patients in whom the risk of post-operative ocular complications of a similar nature might be expected, Tubadil deserves a more extended clinical trial.

We express our thanks to Endo Products Inc., Richmond Hill, N.Y., for supplying the material used in this investigation, and to Dr. Samuel Gordon, Vice-President of the Company, for his willing co-operation and advice. We are also grateful to the surgeons of the Oxford Eye Hospital for their assistance and encouragement during this investigation.

\section{REFERENCES}

FarquHARSON, H. (1951). Amer. J. Ophthal., 34, 554.

FulleR, J. D. (1950). J. Amer. med. Ass., 143, 789.

GORDON, S. M. (Personal communication of unpublished data).

HoвACK, W. W. (1952). J. Tennessee St. med. Ass., 45, 16.

Honey, G. E., DwYer, B. E., SMITH, A. C., and SPALDING, J. M. K. (1954). Brit. med. J., 2, 442.

KIRBY, D. B. (1950). Arch. Ophthal. (Chicago), 43, 678.

Malia, E. R., LuCAS, M. A., Burns, K. O., and Whitacre, R. J. (1954). J. Amer. med. Ass., 156, 7.

Norcross, B. M., RobINS, H. M., and LoCKIE, L. M. (1949). Ibid., 140, 397.

WeEd, M. R., PURVIS, D. F., and WARNKe, R. D. (1948). I Ibid., 138, 1087. 